\title{
УЧАСТЬ ГРОМАДСЬКИХ ТОВАРИСТВ У ФОРМУВАННІ МІСЬКОГО ОСВІТНЬО-КУЛЬТУРНОГО СЕРЕДОВИЩА ПРАВОБЕРЕЖНОЇ УКРАЇНИ (ДРУГА ПОЛОВИНА ХІХ - ПОЧАТОК ХХ СТ.)
}

\author{
О. П. Прищепа
}

Прищепа О. П. Участь громадських товариств у формуванні міського освітньо-культурного середовища Правобережної України (друга половина XIX - початок XX ст.). У статті аналізуються місце і роль громадських товариств у формуванні освітньо-культурного середовища повітових міст та містечок Правобережної України у другій половині XIX - на початку XX ст., розвиток інфраструктури яких поступався губернським центрам. Головний акцент робиться на соціальному спрямуванні освітніх й просвітницьких ініціатив міської спільноти та їх реалізації в міському повсякденні, що прокладало шлях до становлення громадянського суспільства.

Ключові слова: освітньо-культурне середовище; Правобережна Україна; Російська імперія; повітові міста; містечка; громадські товариства.

Прищепа E. П. Участие общественных организаций в формировании городской образовательно-культурной среды Правобережной Украины (вторая половина XIX - начало XX в.). В статье анализируются место и роль общественных организаций в формировании образовательнокультурной среды уездных городов и местечек Правобережной Украины во второй половине ХIX - начале XX в., развитие инфраструктуры которых уступало губернским центрам. Главный акцент делается на социальной направленности образовательных и просветительских инициатив городского сообщества и их реализации в городской повседневности, что прокладывало путь к становлению гражданского общества.

Ключевые слова: образовательно-культурная среда; Правобережная Украина; Российская империя; уездные города; местечко; общественные организации.

Pryshchepa O. P. The Participation of Community Societies in the Formation of Educational and Cultural Environment of Right-Bank Ukraine (Second Half of the $19^{\text {th }}-$ Beginning of the $20^{\text {th }}$ Centuries). The article analyzes the place and role of community societies in the formation of educational and cultural environment of powiat towns and settlements of Right-Bank Ukraine in the second half of the $19^{\text {th }}$ - beginning of the $20^{\text {th }}$ centuries, the development of which was inferior to province centers. The main focus is on social direction of educational and enlightening initiatives of town communities and their implementation in towns' life, which laid foundation for the formation of civil society.

Keywords: educational and cultural environment; Right-Bank Ukraine; Russian empire; powiat towns; settlements; community societies.

Діяльність добровільних громадських асоціацій на теренах Російської імперії не обділена увагою дослідників імперської доби ${ }^{1}$. В останні роки активізувалось їх дослідження на матеріалах українських губерній вітчизняними науковцямиㄹ․ Звернення у цій публікації до діяльності громадських товариств на теренах міського простору Правобережної України опосередковане наміром з'ясувати їх участь у формуванні освітньо-культурного середовища.

Що вкладаємо в концепт «міське освітньо-культурне середовище»? Насамперед систему багаторівневих духовних контактів між представниками міського соціуму у різних лакунах освітньо-культурного життя: навчанні, громадській діяльності, сфері дозвілля тощо. При розгляді цієї проблеми на теренах міського простору Правобережної України у хронологічних межах другої половини XIX - початку XX ст. засадничими виступають два моменти: державне регулювання процесу формування освітньо-культурного середовища і чинники громадських та приватних ініціатив у його творенні містянами різних соціальних, етнорелігійних, професійних груп тощо. Реалізація громадських ініціатив у форматі добровільних асоціацій, безумовно, позначалася на культурному довкіллі міської правобережної глибинки. Підкреслимо, що дослідженню міського освітньо-культурного 
середовища імперської доби на матеріалах українських губерній не приділялося належної уваги, що актуалізує цей напрямок сучасних вітчизняних містознавчих студій.

Беручи до уваги головні адміністративні центри Правобережжя - Київ, Кам'янецьПодільський, Житомир, сконцентруємось усе ж на основному масиві міських поселень, до якого відносилися чотири десятка повітових та заштатних міст та більш як 300 містечок Київської, Волинської й Подільської губерній. Наголосимо, що темпи їх освітньокультурного життя значно поступалися губернським містам та разюче контрастували 3 культурним наповненням Києва - локальної столиці Правобережної України. I все ж у пореформену добу, услід за губернськими містами, в культурному ландшафті повітових міст та містечок з'являються добровільні громадські об'єднання (товариства, клуби, гуртки). Зазвичай подібні асоціації організовувалися за добровільною згодою їх членів, переважно без прямої вказівки місцевої, чи то центральної влади, і мали на меті реалізацію спільних інтересів кола учасників.

3'ясовуючи участь громадських товариств у формуванні освітньо-культурного середовища варто передусім орієнтуватися на ступінь їх задіяння у сфері освітнього і культурного життя міських поселень незалежно від назв асоціацій, які не в повній мірі розкривали різнобічні напрямки їхньої діяльності. Зокрема, багатьом із них були притаманні доброчинні цілі, пов'язані з освітнім життям міст, які не декларувалися напоказ. Зрештою, просвітницькі завдання та культурна організація дозвілля членів товариств була притаманна більшості зареєстрованих громадських об'єднань.

Умовно в діяльності громадських організацій повітових міст та містечок дніпровського Правобережжя можна виділити два етапи: перший окреслюється 70-ми роками XIX - початком XX ст., точкою відліку другого етапу послужило опублікування іменного височайшого указу урядовому Сенату від 4 березня 1906 р. «Про тимчасові правила про товариства і союзи» ${ }^{3}$, а його згортанням - початок Першої світової війни.

Вважаємо, що в рамках першого етапу доцільніше діяльність громадських товариств розглядати у послідовності їх появи у просторах міст. В такому разі виокремлюються наступні групи громадських об'єднань: православні братства; корпоративні клуби соціального і професійного спрямування (дворянські, офіцерські, громадські, ремісничі зібрання); доброчинні товариства (зокрема, товариства допомоги нужденним учням); товариства (гуртки) у сфері культури і науки. 3 домінуванням державного фінансування, однак iз достатньо високим ступенем добровільної участі міського соціуму, на перехресті XIXXX століть у міських поселеннях дніпровського Правобережжя функціонували повітові комітети попечительств про народну тверезість. Заслуговує на увагу спектр просвітницької діяльності й окремих сільськогосподарських товариств.

У рамках другого етапу діяльності громадських товариств прийнятною виглядатиме наступна класифікаційна схема: освітні та просвітницькі товариства (головно займалися заснуванням навчальних закладів, формуванням читацьких зацікавлень містян); благодійні товариства; літературно-артистичні об'єднання; організації клубного типу тощо.

Одними з перших публічну діяльність у повітових містах та містечках Правобережжя від 70-х років почали розгортати православні братства. Затиснуті в лещата чітко окресленої законодавством сфери місіонерської діяльності ${ }^{4}$, окремі 3 них розгорнули різнопланову освітньо-культурну роботу включно з утриманням братських шкіл, організацією народних читань та масових заходів релігійного спрямування, пам'яткоохоронною, видавничою, бібліотечною діяльністю, книгорозповсюдженням, проведенням краєзнавчих досліджень і навіть заснуванням музеїв. Саме таку розширену програму діяльності демонстрували Хрестовоздвиженське братство у Луцьку (1873), Святоволодимирське братство у Володимирі-Волинському (1887), а на початку XX ст. братство князів Острозьких у Острозі

I все ж високий ступінь громадської активності не був притаманний більшості організацій братського руху на всьому міському просторі Правобережної України, а наприкінці імперського періоду (1913) їхня діяльність, окрім губернських центрів, фіксувалася лише у Володимирі-Волинському, Луцьку, Острозі, Старокостянтинові, містечку Волочиськ, Вінниці (зауважимо, переважно на теренах Волинської губернії) 6 .

Від початку 70-х рр. XIX ст. у повітових містах та містечках Правобережної України набувають поширення добровільні об'єднання (клуби) для проведення дозвілля поки що досить обмеженого кола привілейованих груп міського населення - дворян, військових: 
дворянські і військові зібрання, а наприкінці XIX ст. із більш широким соціальним чи то професійним представництвом - громадські й ремісничі зібрання. Безумовно, дворянські й військові зібрання були асоціаціями винятково соціальної еліти, відповідно, із обмеженим числом членів, яких об'єднували спільні статутні положення та процедура виборів. Наголосимо, що клубна спільнота дворян, або ж військових не лише спільно розважалася традиційною картярською грою чи то танцювальними дійствами, а й задовольняла особисті читацькі уподобання шляхом організації клубних бібліотек, долучалася до благодійних акцій, комунікувала з іншими громадськими об'єднаннями у повітових містах.

Олександр Гриценко слушно зауважував, що марно було б шукати якогось українського духу у подібного роду станових зібраннях ${ }^{7}$. Та все ж Олена Пчілка (О. Косач) у спогадах зафіксувала цікаві особисті спроби наприкінці 1870-х - початку 1880-х рр. надати дворянському та одному з офіцерських клубів у повітовому Луцьку крихту українського забарвлення. На відміну від Новограда-Волинського, де довгий час мешкала іiі родина (1871-1878), світське життя у Луцьку сприймалося «люднішим»: давалося взнаки квартирування військових, до того ж іiі чоловік - Петро Косач, обіймаючи посади повітового предводителя дворянства і голови з'їзду мирових суддів, повинен був брати участь і в клубному житті. «Вийшло так, що я вступила в Луцьке драматичне товариство і мені довелось закласти в Луцькому камінчик української культури. Коли зібралось трохи грошей 3 двох спектаклів, де я була головною учасницею, я запропонувала - i це було охоче прийнято, - щоб для клубної бібліотеки виписано було самих-но українських книжок, бо до тієї пори таких книжок у клубній бібліотеці не було. Повинна я сказати, що члени клубу не робили перешкод при заснуванні українського відділу в бібліотеці, а, навпаки, сприяли тому. Так було не тільки в «Общественном собрании», а й у «Офицерском собрании» драгунського полку...» ${ }^{8},-$ згадувала Олена Пчілка.

Варто наголосити, що верховна влада навіть в умовах, коли вже повним ходом в імперії реалізувалися реформи (1860-1870-ті рр.) не поспішала надавати дозволи для розгортання діяльності благодійних організацій навіть у губернських містах Правобережжя, зважаючи на нещодавнє польське Січневе повстання. Ось чому у культурному повсякденні повітових міст і містечок Правобережжя подібні товариства утверджуються лише наприкінці XIX -початку XX ст., поєднуючи вирішення соціальних проблем найменш захищених містян з організацією культурного дозвілля.

Зауважимо, що доброчинні громадські організації на кшталт товариств допомоги бідним мешканцям міст, задовольняючи суто християнські чесноти своїх членів у реалізації благодійних намірів, згідно статутних вимог, спрямовували зусилля не лише на покращення матеріального стану бідних прошарків міського населення, а й на духовне, відтак культурне наповнення їхнього життя потребою у читанні книжок, створенням умов для здобуття елементарної, чи то професійної (ремісничої) освіти. Одним із засобів поповнення коштів на подібні цілі виступала організація концертів, спектаклів власними аматорськими силами, як, скажімо, це демонстрували члени товариств допомоги бідним Рівного й Ковеля 9 .

Прикметно, що до участі у благодійних товариствах активно залучалося жіноцтво, реалізуючи у такий спосіб соціальну потребу бути у вирі міського громадського життя. Безумовно, як і решта членів добродійних товариств, жіноче представництво належало переважно до заможних прошарків міського населення й з готовністю включалося до будь-якої громадської роботи у межах статутних положень товариств.

Найтісніше поміж благодійних товариств 3 освітньою і ширше -культурною сферою міського життя були пов'язані товариства допомоги нужденним учням. Зазвичай територія їхньої діяльності обмежувалася конкретними міськими навчальними закладами. Якщо спочатку під їхню опіку потрапляли найбідніші учні середніх шкіл (чоловічих гімназій, реальних училищ), то від кінця XIX ст. ще й потребуючі матеріальної допомоги учні початкових навчальних закладів, комерційних училищ, учениці жіночих гімназій.

Окрім суто матеріальної підтримки допомога бідним учням реалізувалася шляхом безкоштовної роздачі книжок, чи то продажу їх за низькими цінами. Стабільним джерелом доходів указаних товариств слугували організовані власними силами театральні вистави, концерти, літературні читання, публічні лекції. Впадає в очі, що участь у подібних доброчинних організаціях брало широке представництво містян різних соціальних прошарків 
та етнічних груп. Поміж чиновників повітових державних установ, очільників міського і станового самоврядування тут бачимо учителів, лікарів й інших представників міської інтелігенції.

Варто відзначити плідні контакти правлінь товариств допомоги нужденним учням 3 іншими добровільними організаціями, зокрема ще слабко поширеними у повітових містах та містечках мистецькими об’єднаннями. Так, у Рівному на початку 1890-х рр. тісні взаємини на ниві організації культурних заходів були налагоджені між товариством допомоги нужденним учням Рівненського реального училища та місцевим гуртком любителів драматичного мистецтва ${ }^{10}$.

Наприкінці XIX - початку XX ст. значний обсяг просвітницької роботи у повітових містах та містечках дніпровського Правобережжя здійснювали повітові комітети попечительств про народну тверезість. Підкреслимо, що у повній мірі громадськими добровільними об'єднаннями їх вважати не варто, оскільки вони усе ж були «дітищем» імперської влади, зокрема, Міністерства фінансів, від якого й отримували основні кошти для розгортання своєї діяльності. Створені в умовах уведення державної монополії на продаж алкогольних напоїв, подібні асоціації мали не лише наглядати за дотриманням умов торгівлі спиртними напоями, а й пропагувати здоровий спосіб життя шляхом організації культурного дозвілля населення через такі канали комунікації, як народні бібліотеки, недільні школи чи то класи для дорослих, народні чайні та доми (клуби), масові гуляння без алкогольних напоїв тощо ${ }^{11}$.

До участі в роботі попечительств на добровільних началах зазвичай зголошувалося широке коло освічених містян. Так, у 1897 р. розмаїтий соціальний і професійний склад демонстрував Вінницький повітовий комітет попечительства про народну тверезість, поширюючи свою діяльність не лише у Вінниці, а й у Жмеринці, Брацлаві та низці містечок. Зі 115 його членів 27 осіб мешкало в самій Вінниці, а поміж членів-змагальників (96 осіб) найбільше було священослужителів (24), учителів та учительок (23), чиновників і офіцерів (18), представників вільних професій - лікарів, фельдшерів, архітектор, інженерів-техніків, землемірів (8 осіб) тощо ${ }^{12}$. Слід віддати належне представникам педагогічної професії, які незалежно від скромної винагороди своєї праці у комітетах попечительств, а найчастіше безкоштовно, зголошувалися на посади бібліотекарів народних читалень, не відмовлялися від лекторської роботи ${ }^{13}$. Однак обмежені у державному фінансуванні на початку XX ст. повітові комітети попечительств про народну тверезість змушені були згорнути свою діяльність.

За відсутності розгалуженої мережі громадських товариств на межі XIX-XX ст. помітну роль у культурному житті містян відігравали сільськогосподарські товариства, зокрема, у Рівному, Луцьку, Володимирі-Волинському, Умані, Вінниці та деяких інших міських поселеннях. Поміж них унікальний досвід просвітницької діяльності демонструвало Рівненське сільськогосподарське товариство, засноване у 1900 р. Якщо налагодити випуск періодичного видання та відкрити бібліотеку вказаному товариству не вдалося, то музейний проект, починаючи від 1906 року, таки був реалізований завдяки зусиллям виконуючого обов'язки голови товариства Е. Окенцького. Однак марно було шукати у двох кімнатах складу-магазину, де були виставлені на огляд предмети музейного значення, колекцій насіння найбільш врожайних посівних культур, чи то зразків грунтів, як то б годилося для сільськогосподарського профілю музею. Головними його експонатами стали місцеві старожитності, чималий пласт яких мав відношення до боротьби за незалежність польського люду в умовах Російської імперії ${ }^{14}$.

Прикметно, що Подільське товариство сільського господарства і сільськогосподарської промисловості своїм осідком обрало не губернський центр, а повітову Вінницю, де була облаштована виставка досягнень сільського господарства, відвідувана багатьма вінничанами та гостями міста із різних куточків Поділля ${ }^{15}$.

Якщо у сільськогосподарських товариствах, які охоплювали переважно місцевих землевласників, чітко простежувалася культурна спрямованість на підтримку польської присутності у Правобережній Україні, то товариства у сфері культури й мистецтва принаймні до революційних подій 1905 р. усе ж об'єднували навколо себе представництво інтелігенції різних етнічних груп міського населення. Адже захоплення музикою, драматичним мистецтвом не залежало від етнічної приналежності. Про те, що спільне громадське жит- 
тя обмежувалось в Умані літературно-художнім гуртком та ще громадською бібліотекою, пригадувала Н. Суровцова ${ }^{16}$.

Підсумовуючи перший етап діяльності громадських товариств варто наголосити на їх слабких рефлексіях у формуванні культурного довкілля повітових міст та містечок Правобережної України. Особливо це впадає в очі на фоні активності громадськості Києва ${ }^{17}$, що засвідчувало про ледь-помітні у них потуги до закладання основ громадянського суспільства. Державне регулювання їхньої присутності в культурному просторі міст налаштовувало на поступове, та все ж неминуче стирання культурних відмінностей між багатоетнічним представництвом міського соціуму. Однак революційні події 1905-1906 рр. послужили сигналом до творення «культурних світів» кожною етнічною громадою окремо - але, що важливо, уже на нових засадах, - без жорстких станових перегородок між членами добровільних асоціацій.

Як і повсюди в імперії Романових, у повітових містах та містечках Правобережної України кількість громадських асоціацій відчутно починає зростати після опублікування 4 березня 1906 р. «Тимчасових правил про товариства і союзи». Відтепер заяви про реєстрацію добровільних об'єднань розглядали губернські у справах про товариства присутствія, що значно пришвидшило шлях до інституалізації різноманітних форм самоорганізації містян ${ }^{18}$.

Відзначимо певну зацікавленість міського загалу на початку XX ст. в організації добровільних об'єднань, які ставили за мету поширення різних форм освіти поміж міського населення, займаючись при цьому й суто просвітницькою роботою. Особливо важливо це було для містечок та приватновласницьких міст, самоврядування яких не мало відповідних фінансових ресурсів, щоб належним чином розвивати шкільництво. Від 1909 р. показовий досвід у справі відкриття та організації життєдіяльності чоловічої й жіночої гімназій демонструвало навчально-просвітницьке товариство в містечку Смілі Київської губернії, у складі якого нараховувалося більше 200 осіб $^{19}$.

Підкреслимо, що шляхом безпосередніх контактів між громадськими об'єднаннями, приватними особами, різними установами, яких об'єднувала спільна ціль - облаштування у міських поселеннях навчальних закладів, і відбувалося формування міського освітньокультурного середовища. I все ж розгорнути дієву роботу по організації нових навчальних закладів громадським товариствам у міських поселеннях Правобережної України було не під силу. Зокрема, створене у 1908 р. Товариство сприяння середній освіті у Рівному задекларувало відкриття чоловічої гімназії, але не реалізувало своїх задумів. Непідйомною виявилася ціль і для навчально-просвітницького товариства у волинському містечку Радзивилові, а саме, облаштування та утримання гімназії, чи то реального училища, а чи якогось іншого навчально-виховного закладу для місцевих потреб, тому, проіснувавши близько чотирьох років, згорнуло свою діяльність ${ }^{20}$. Засноване у 1912 р. Товариство поширення комерційної освіти для осіб обох статей у містечку Козятин Київської губернії збиралося відкрити торговельні класи або ж комерційні курси, однак також потерпіло фіаско ${ }^{21}$. Міркуємо, що перепони у розгортанні їхньої діяльності слід шукати не лише у площині їх фінансової неспроможності, а й у слабкості організаторських потуг для досягнення поставлених цілей.

Звернемо увагу на чітку тенденцію до поширення від 1906 р. у повітових містах та містечках Правобережжя усе більшої кількості нових громадських об'єднань, які, переслідуючи різні цілі, як-то просвітництво, благодійництво, організацію культурного дозвілля тощо, об'єднували у своїх лавах представників лише однієї етнічної міської спільноти - чи то польської, чи то єврейської, i, врешті, української. Назагал саме такі складники культурного життя пришвидшували націотворення конкретних етнічних спільнот у міській правобережній глибинці. Однак подібні процеси не сприяли формуванню цілісного для усіх містян освітньо-культурного середовища, де кожен незалежно від ідентифікації з конкретною етнічною спільнотою міг асоціювати себе приналежним до усього міського загалу.

Як відомо, інституалізація українських громадських осередків розпочалася лише після 1906-1907 рр., коли була дозволена діяльність «Просвіт», які ставили за мету сприяння розвиткові української культури і головним чином просвіті українського народу його рідною мовою. Розгортаючи свою діяльність насамперед у губернських містах 
Правобережжя - Києві, Житомирі і Кам'янці-Подільському, вони мали дозвіл поширювати ії по всій території трьох правобережних губерній, однак небагато встигли зробили у повітових містах ${ }^{22}$.

Найбільш відомо про філію подільської «Просвіти», яка від червня 1906 р. постала у Могилеві-Подільському. Вона гуртувалася навколо тижневика «Світова зірниця» на чолі 3 редактором Й. Волошиновським - відомим організатором кооперативного руху на Поділлі ${ }^{23}$. Так, 1 червня 1906 р. «Світова зірниця» повідомляла, що «багато чого доброго товариство задумало... може Бог дасть, що в нашій редакції скоро буде відділ товариства Просвіти і ми хоч чим небудь в тій потрібній просвітницькій праці помогти зможемо». I дійсно, вже 2 липня 1906 р. управа Могилівського відділу подільської «Просвіти» заявила про себе організацією спектаклю, дохід з якого у сумі 58 руб. планувала використовувати на різні освітянські справи ${ }^{24}$. $Є$ згадка про ще одну філію подільської «Просвіти», засновану у містечку Дунаївцях, однак без деталізації іiї діяльності ${ }^{25}$.

На фоні усе ще слабких потуг українців до громадської діяльності у повітових містах Правобережжя від 1906 р. упевнено про свою згуртованість заявила польська громадськість, долаючи перепони на шляху до реєстрації своїх товариств. За даними реєстру Волинського губернського у справах про товариства присутствія клопотання про реєстрацію подавали ті польські громади, які збиралися займатися насамперед благодійництвом: це римо-католицькі благодійні товариства у Луцьку і Заславлі (1906), Ковелі (1911), Рівному (1914), Олиці (1914). Поміж них без перешкод зареєстрували лише Заславське та Олицьке римо-католицькі благодійні товариства ${ }^{26}$.

Висловлювали губернські у справах про товариства присутствія претензії і до побажань поляків мати власні клубні осередки, тому не всі із них успішно проходили реєстрацію. Довідкове видання «Весь Юго-Западный край» зафіксувало у 1913 р. діяльність польських громадських організацій і культурних центрів у таких повітових містах Правобережжя: Умані (польський жіночий гурток), Луцьку (польське зібрання), Вінниці (громадський польський гурток), Могилеві-Подільському (польський дім), Новій Ушиці (римо-католицьке товариство $)^{27}$.

На хвилі суспільного підйому в Російській імперії в окремих містах Волині активізувалася ще й малочисельна чеська община, зокрема, у Здолбунові (1910) планувала створити доброчинне і просвітницьке товариство, на що так і не отримала офіційного дозволу ${ }^{28}$.

Та все ж від 1906 р. найвищу громадську активність проявила єврейська спільнота, спираючись на досвід традиційної благодійності, наслідки державної політики інтеграції в російське суспільство, а притаманна ій наполегливість та згуртованість допомагала долати бюрократичні перепони. Поміж єврейських громадських об'єднань виокремимо такі, які ставили за мету поширення освіти поміж своїми єдиновірцями. Показовим у цьому плані було Товариство сприяння початковій і професійній освіті серед жіночого єврейського населення м. Умані (1911-1912), яке згуртувало навколо себе близько 340 осіб, що займалися організацією грошової допомоги жіночому єврейському училищу Д. Теплицької, збором старого одягу та дитячих книжок для його учениць, поповненням шкільної бібліотеки новими надходженнями ${ }^{29}$.

Бралася єврейська спільнота (хоча не завжди успішно) й за організацію бібліотечних товариств, як от у Немирові (1914), і в такий спосіб намагалася «дать возможность местному еврейскому населению пользоваться книгами и периодическими изданиями на доступных ему языках» ${ }^{30}$. Загалом незалежно від основного напрямку діяльності єврейські товариства покладали на себе ще й додаткові функції, зокрема, освітні, чи то просвітницькі.

Констатуємо, що хоча низка громадських товариств у повітових містах та містечках Правобережної України скеровувала свою діяльність у русло культурної взаємодії з усім міським соціумом, водночас їх діяльність усе ж поглиблювала відособленість етноконфесійних громад. На це відповідним чином реагувала місцева влада, керуючись циркуляром Міністерства внутрішніх справ від 20 січня 1910 р. про заборону реєстрації тих товариств, в діяльності яких могли домінувати просвітницькі цілі, оскільки, як стверджувалось, вони могли бути спрямовані «на почве исключительно национальных интересов во вред коренному русскому населению и обострению вражды с этим населением» ${ }^{31}$.

У результаті міське освітньо-культурне середовище Правобережжя залишалося сепарованим на культурні сектори - єврейський, польський, український. Окрім того, членство 
в організаціях передбачало сплату грошових внесків, що слугувало певним бар'єром для консолідації як окремих етнічних груп населення, так і в цілому міського соціуму.

Насамкінець варто підкреслити слабкість ініціатив містян повітових міст та містечок Правобережної України у заснуванні громадських товариств упродовж усього розглянутого періоду. У 1913 р. до двох десятків громадських об'єднань фіксувалося лише в окремих міських поселеннях, які демонстрували найвищі показники культурного розвитку (Умань, Вінниця, Луцьк, Рівне), а в переважній більшості повітових міст їх нараховувалося буквально одиниці. За приблизними підрахунками, в окремо взятому повітовому місті Дніпровського Правобережжя участь у їхній діяльності могли брати від декількох десятків до двох-трьох сотень освічених і переважно забезпечених містян.

Поширеною була практика, коли по завершенні реєстрації добровільні асоціації так і не приступали до своєї діяльності, або ж функціонували номінально. Та попри все громадські товариства виступали школою здобуття нового соціального досвіду містян на шляху до самоорганізації міського життя, що позитивно позначалось на їх освітньо-культурному середовищі та прокладало шлях до становлення громадянського суспільства.

${ }^{1}$ Степанский А. Д. История общественных организаций в России на рубеже XIX-XX вв. Пособие по спецкурсу. Под ред. Н. П. Ерошкина. М.: МГИАИ, 1982. 96 с.; Линденмейер А. Добровольные благотворительные общества в эпоху Великих реформ // Великие реформы в России. 1856-1874: Сб. / Под ред. Л. Г. Захаровой, Б. Эклофа, Дж. Бушнелла. М.: Издательство Московского университета, 1992. С. 283-300; Зорин A. Н., Клюшина E. B. Общественные организации городов // Очерки городского быта дореволюционного Поволжья. Ульяновск: Издательство «Средневолжского научного центра», 2000. С. 416-467; Миронов Б. Н. Добровольные ассоциации и гражданское общество в позднеимперской России // Журнал социологии и социальной антропологии. 2008. Т. ХІ. С. 164-176; Туманова А. С. Общественные организации и русская публика в начале XX века. М.: Новый хронограф, 2008. 320 с.; Бредли Дж. Общественные организации в царской России: наука, патриотизм и гражданское общество: пер. с англ. М.: Новый хронограф, 2012. 448 с.

${ }^{2}$ Бойчук Я. А. Громадські об'єднання етноменшин на українських землях у складі Російської імперії (1861-1914): дис ... канд. іст. наук. К., 2015. 273 с.; Оліпер С. I. Громадсько-політичне життя польської меншини Правобережної України 90-х рр. XIX ст. - на початку XX ст.: дис ... канд. іст. наук. Кам'янець-Подільський, 2016. 275 с.; Македон В. В. Національно-культурні об'єднання Одеси в другій половині XIX - на початку XX століття: виникнення, склад та діяльність: автореф. ... дис.. канд. іст. наук. Одеса, 2017. 18 с.

${ }^{3}$ Российское законодательство Х-ХХ вв. В 9-ти т. Т. 9. М., 1994. С. 200-217.

${ }^{4}$ Полное Собрание Законов Российской империи. Собрание второе. СПб., 1867. Т. XXXIX. Отделение первое. 1864. Мая 8. № 40863. Высочайше утвержденное положение Комитета Министров, распубликованное 10 июня. О правилах для учреждения Православных церковных братств. C. 409-410.

5 Гаврилюк C. Історичне пам'яткознавство Волині, Холмщини і Підляшшя (XIX - початок XX ст.): Монографія. 2-е вид., доп. Луцьк: РВВ «Вежа» Волин. нац. ун-ту ім. Лесі Українки, 2008. С 180-181, 218; Сажок О. В. Культурно-просвітницька діяльність церковних православних братств Волинської губернії у другій половині XIX - на початку XX ст.: автореф. ... дис. канд. іст. наук. Луцьк, 2012. 20 с.; О. Л. [О. И. Левицкий]. Владимир-Волынское братство: (По поводу его первого годичного отчета) // Киевская старина.1889. Июль. Т. XXXVI. С. 285-289.

${ }^{6}$ Весь Юго-Западный край. Издание Юго-Западного Отделения Российской Экспортной Палаты. К.: Типография и писчебумажный магазин А. И. Гросмана. 1913. С. 594, 719, 797, 844, 880, 883, 904, 962.

${ }^{7}$ Гриценко О. Клуб // Нариси української популярної культури / за ред. О. Гриценка. К.: Б. в., 1998. C. 246.

${ }^{8}$ Олена Пчілка. 3 біографії // Спогади про Лесю Українку. Видання друге, доп. К.: Видавництво художньої літератури «Дніпро», 1971. С. 82.

${ }^{9}$ Отчет правления общества вспомоществования бедным г. Ровно за 1903 год (Шестой отчетный год). Ровно: Типо-литография М. А. Бренера, 1904. С. 9-10; Отчет правления Ковельского общества вспомоществования бедным за 1902 год. Ковель: Типо-литография Л. Нахамкина и М. Чертова, 1903. C. 5.

${ }^{10}$ Центральний державний історичний архів України, м. Київ (далі - ЦДІАК України). Ф. 442. Оп. 528. Спр. 465. Арк. 1; Державний архів Рівненської області. Ф. 215. Оп. 2. Спр. 21. Арк. 28.

${ }^{11}$ Устав Попечительства о народной трезвости (Высочайше утвержден 20 декабря 1894 г.). Житомир: Волынская губернская типография, 1896.9 с.

${ }^{12}$ Державний архів Вінницької області. Ф. 244. Оп. 1. Спр. 18. Арк. 3, 19, 22. 
${ }^{13}$ ЦДІАК України. Ф. 707. Оп. 227. Спр. 41. Арк. 12, 15.

${ }^{14}$ Прищепа О. П. Музей у культурному житті Рівного початку XX ст. // Краєзнавство та музейна справа в Україні. Матеріали Всеукр. наук.-краєзн. конф. Житомир: М. Косенко, 2010. С. 24-27.

${ }^{15}$ Dziennik Kijowski. 1912. 24 sierpnia. № 211. С. 2; Колесник B. Подільське товариство сільського господарства і сільськогосподарської промисловості (1896-1918). Іст. нарис. Вінниця: Розвиток, 2007. C. $105-106$.

${ }^{16}$ Життя Надії Суровцової // Наука і культура. К.: Товариство «Знання» УРСР, Академія наук УРCP, 1990. С. 431

${ }^{17}$ Ступак $Ф$. Я. Діяльність благодійних товариств Києва другої половини XIX - початку XX ст: дис ... канд. іст. наук. К., 1997. 210 с.

18 Прищепа Е. Добровольные общественные организации в культурном пространстве городских поселений Подольской губернии в начале XX века // Wschodni Rocznik Humanistyczny. 2013. T. IX. Lublin-Radzyn Podlaski. S. 155-166; Леснича П. Виникнення та основні напрямки діяльності громадських товариств у Волинській губернії на початку XX ст. // Актуальні проблеми вітчизняної та всесвітньої історії: Наукові записки Рівненського державного гуманітарного університету. Вип. 26. 2015. С. 224-227.

19 Отчет Правления учебно-просветительного Общества в Смеле от 1-го августа 1909 по 1-е января 1911 г. Смела: Тип. В. Лепского, 1911. С. 3.

${ }^{20}$ Державний архів Житомирської області (далі - ДАЖО). Ф. 329. Оп. 1. Спр. 3. Арк. 22зв., 35.

21 Устав Общества распространения образования для лиц обоего пола в м. Казатин Киевской губернии. Казатин: Тип. Л. Л. Лившица, 1912. С. 2.

22 Устав Украинского общества «Просвіта» в Житомире / Статут Українського товариства «Просвіта» у Житомирі. Житомир: Тип. Е. И. Щербицкого, 1907. С. 3; Устав Подольского Украинского Общества «Просвіта». Каменец-Подольский: Типография С. П. Киржацкого, Б. г. С. 4.

${ }^{23}$ Баженов Л. В., Кучеров Г. Г. Основні етапи діяльності подільських «Просвіт» у 1906-1923 pp. // Освіта, наука і культура на Поділлі. Зб. наук. праць. Кам’янець-Подільський: Оіюм, 2009. Т. 13. C. 83-91.

${ }^{24}$ Світова зірниця. Могилів-Подільський. 1906. 1 червня. № 15. С. 7; Світова зірниця. МогилівПодільський. 1906. 27 липня. № 23. С. 11.

${ }^{25}$ Герасименко В. 3 українського громадського руху на Поділлі (1905-1917) (Пам'яті д-ра К. Г. Солухи) // За сто літ. Матеріяли з громадського і літературного життя України XIX і початків XX століття за редакцією академіка Михайла Грушевського. Кн. 5. Харків-Київ: Державне видавництво України, 1930. С. 306.

${ }^{26}$ ДАЖО. Ф. 329. Оп. 1. Спр. 3. Арк. 2; ДАЖО. Ф. 329. Оп. 1. Спр. 78. Арк. 1, 39; ДАЖО. Ф. 329. Оп. 1. Спр. 130. Арк. $1,4$.

${ }_{27}^{27}$ Весь Юго-Западный край. Издание Юго-Западного Отделения Российской Экспортной Палаты. К.: Типография и писчебумажный магазин А. И. Гросмана. 1913. С. 610, 797, 958, 1014, 1057.

${ }_{28}^{28}$ ДАЖО. Ф. 329. Оп. 1. Спр. 45. Арк. 1, 35.

29 Отчет Общества содействия распространению начального и профессионального образования среди женского еврейского населения г. Умани за 1911-12 учебный год. (с 1 августа 1911 г. по 1 августа 1912 г.). Умань: Типография «Энергия», 1913. 31 с.

${ }_{30}$ Державний архів Хмельницької області. Ф. 629. Оп. 1. Спр. 119. Арк. 9зв.

31 Українська ідентичність і мовне питання в Російській імперії: спроба державного регулювання (1847-1911). Збірник документів і матеріалів. К.: Ін-тут історії України НАН України, 2013. С. 457. 